\title{
On two pterosaur humeri from the Tendaguru beds (Upper Jurassic, Tanzania)
}

\author{
FABIANA R. COSTA and ALEXANDER W.A. KELLNER \\ Museu Nacional, Universidade Federal do Rio de Janeiro, Departamento de Geologia e Paleontologia \\ Quinta da Boa Vista s/n, São Cristóvão, 20940-040 Rio de Janeiro, RJ, Brasil \\ Manuscript received on August 17, 2009; accepted for publication on September 30, 2009; \\ contributed by AlEXANDER W.A. KELLNER*
}

\begin{abstract}
Jurassic African pterosaur remains are exceptionally rare and only known from the Tendaguru deposits, Upper Jurassic, Tanzania. Here we describe two right humeri of Tendaguru pterosaurs from the Humboldt University of Berlin: specimens MB.R. 2828 (cast MN 6661-V) and MB.R. 2833 (cast MN 6666-V). MB.R. 2828 consists of a threedimensionally preserved proximal portion. The combination of the morphological features of the deltopectoral crest not observed in other pterosaurs suggests that this specimen belongs to a new dsungaripteroid taxon. MB.R. 2833 is nearly complete, and because of a long and round proximally placed deltopectoral crest it could be referred to the Archaeopterodactyloidea. It is the smallest pterosaur from Africa and one of the smallest flying reptiles ever recorded. These specimens confirm the importance of the Tendaguru deposits for the Jurassic pterosaur record. This potential, however, has to be fully explored with more field work.
\end{abstract}

Key words: Tendaguru, Tanzania, Africa, Upper Jurassic, Pterosauria.

\section{INTRODUCTION}

Africa shows a great potential for pterosaur material due to the extensive outcrops in several areas. However, pterosaur remains have been found only in nine African countries (Kellner et al. 2007) and, prior to 1997, just postcranial material had been reported (Reck 1931, Galton 1980, Mader and Kellner 1999, Wellnhofer and Buffetaut 1999). Recently new deposits were found with associated bones, including a partial wing from Lebanon (Dalla Vecchia et al. 2001) and a sequence of five cervical vertebrae from Morocco (Pereda-Superbiola et al. 2003). The red beds of Albian Cenomanian age from Morocco and Late Jurassic Tendaguru beds, located approximately $75 \mathrm{~km}$ northwest of Lindi, Tanzania (Maier 1997), are the most potential deposits

\footnotetext{
*Member Academia Brasileira de Ciências Correspondence to: Fabiana Rodrigues Costa E-mail: fabiana.costa@ufrj.br
}

in providing isolated remains up to now (Kellner and Mader 1997, Wellnhofer and Buffetaut 1999, Mader and Kellner 1999).

Regarding Tendaguru beds, four species were first established by the pioneer studies of Reck (1931): "Rhamphorhynchus" tendagurensis (based on radius and ulna), "Pterodactylus" maximus (based on a comparatively large ulna), "Pterodactylus" brancai (based on a tibiotarsus, fibula and the first phalanx of the wing finger), and "Pterodactylus" arningi (based on the first phalanx of the wing finger). Later, Galton (1980) reviewed the tibiotarsus from "Pterodactylus" brancai and reclassified it as "Dsungaripterus brancai" (Dsungaripteridae). However, all those specimens are too fragmentary or incomplete for any determination at a species level, being regarded as nomina dubia by Unwin and Heinrich (1999). These authors also described a new taxon (Tendaguripterus recki) based on 
a short section of a mandibular symphysis. Afterward Sayão and Kellner (2001) briefly discussed part of Tendaguru pterosaur collection and mentioned the existence of the two humeri, which are here described in detail. We follow Kellner and Tomida (2000) regarding the orientation of the bones.

\section{GEOLOGICAL SETTING}

The deposits of the Tendaguru beds are divided into Lower, Middle and Upper Saurian beds (Janensch 1914). Transitional deposits between the Saurian beds and the marine units were formally recognized as Transitional Sands (Übergangsschichten) (Heinrich 1999). Most of pterosaur remains were possibly recovered from the Upper Saurian bed and the Transitional Sand at the base of the Upper Saurian bed (Reck 1931). According to Unwin and Heinrich (1999), pterosaurs are rare in the Middle Saurian bed and absent in the Lower Saurian bed and marine units, but this can be due to collecting bias (Fig. 1).

Although isolated, all known pterosaur elements from those deposits are preserved in three dimensions, albeit some crushing is perceptible.

\section{SYSTEMATIC PALEONTOLOGY}

Pterosauria Kaup, 1834

Pterodactyloidea Plieninger, 1901

Dsungaripteroidea Young, 1964

Dsungaripteroidea indet.

Material: Proximal portion of a right humerus housed at the Naturkundemuseum of the Humboldt University (MB.R. 2828), Berlin; cast at the Museu Nacional/UFRJ (MN 6661-V), Rio de Janeiro.

Description: The specimen MB.R. 2828 (Fig. 2; Table I) has a slightly dorso-ventral compression, showing several fractures. It possesses the characteristic saddleshaped proximal articular head, common to the pterosaur humeri. The deltopectoral crest is well developed and inclined proximoventrally. It is tongue-shaped with a rounded distal end. In lateral view the proximal margin of the deltopectoral crest is markedly concave, while the distal margin is straight. There is an elongated ridge on the medial side of the crest running from the distal

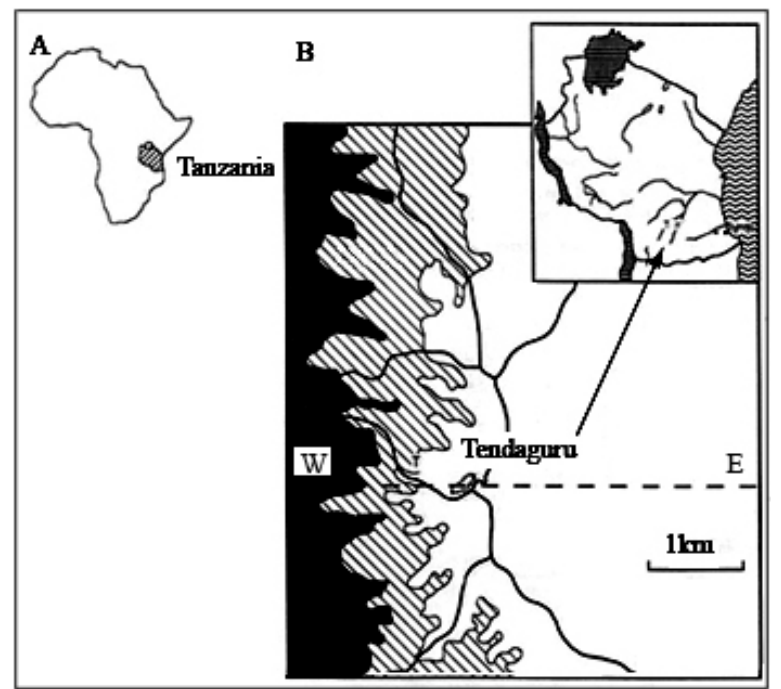

Fig. 1 - Locality map. A. Africa, showing the location of Tanzania. B. Tendaguru site (adapted from Unwin and Heinrich 1999).

to the proximal edge, and is likely an attachment of a flight muscle ( $m$. pectoralis, see Bennett 2003). There is an elongated concavity on the medial side, close to the distal margin, whose function is unknown. The ulnar crest is blunt and slightly crushed laterally. The dorsal margin shows a well developed pneumatic foramen, located close to the lateral side.

\section{Archaeopterodactyloidea Kellner, 2001}

Archaeopterodactyloidea indet.

Material: Complete right humerus housed at the Naturkundemuseum of the Humboldt University (MB.R. 2833), Berlin; cast at the Museu Nacional/UFRJ (MN 6666-V), Rio de Janeiro.

Description: The specimen MB.R. 2833 (Fig. 3; Table II) is nearly complete, lacking only the lateral portion of the ulnar crest. It is quite small (total length of $25.5 \mathrm{~mm}$ ) but, based on the bone texture and the articulation surface, appears not to represent a very ontogenetically immature animal (Bennett 1993, Kellner and Tomida 2000). It lacks pneumatic foramina both at ventral and dorsal surfaces. The deltopectoral crest is proximally placed with the main axis directed almost perpendicular to the humerus shaft. The base is broad, thinning gradually to the distal tip, giving the deltopectoral crest a sub-triangular shape. 

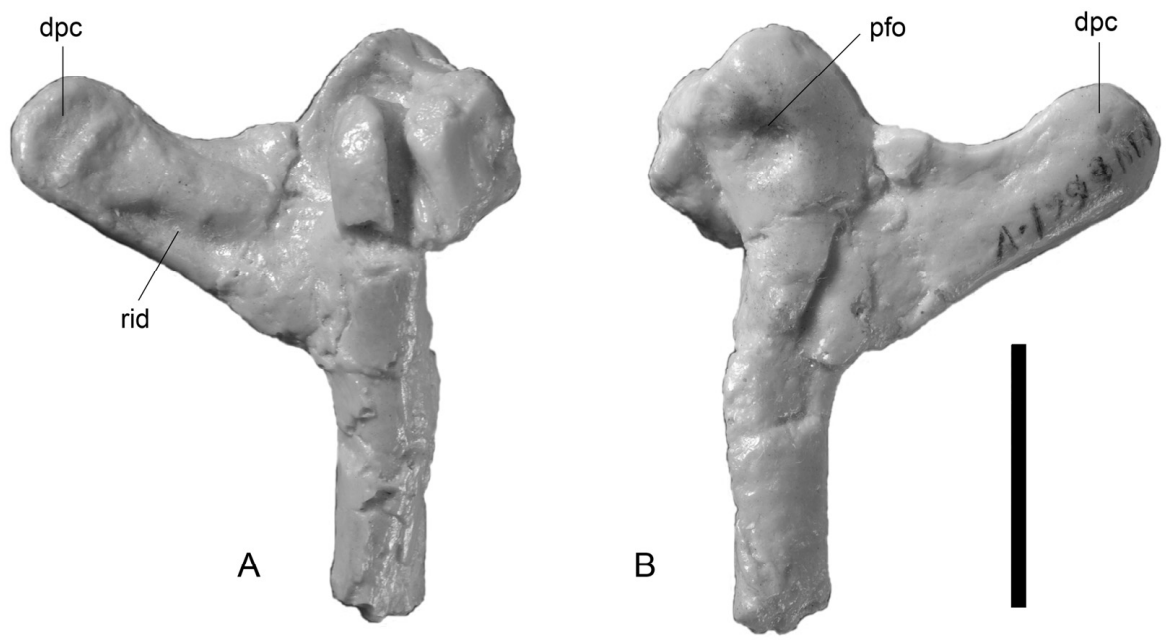

Fig. 2 - Specimen MB.R. 2828 in: A. medial view, B. lateral view; dpc - deltopectoral crest; pfo - pneumatic foramen; rid - ridge (scale $2 \mathrm{~cm}$ ).

TABLE I

Measurements (in mm) of MB.R. 2828.

\begin{tabular}{l|c}
\hline \multicolumn{1}{c|}{ Measurement } & Value \\
\hline Deltopectoral crest lenght & 22.20 \\
\hline Length of attachment of deltopelctoral crest & 17.90 \\
\hline Proximal width & 38.65 \\
\hline
\end{tabular}
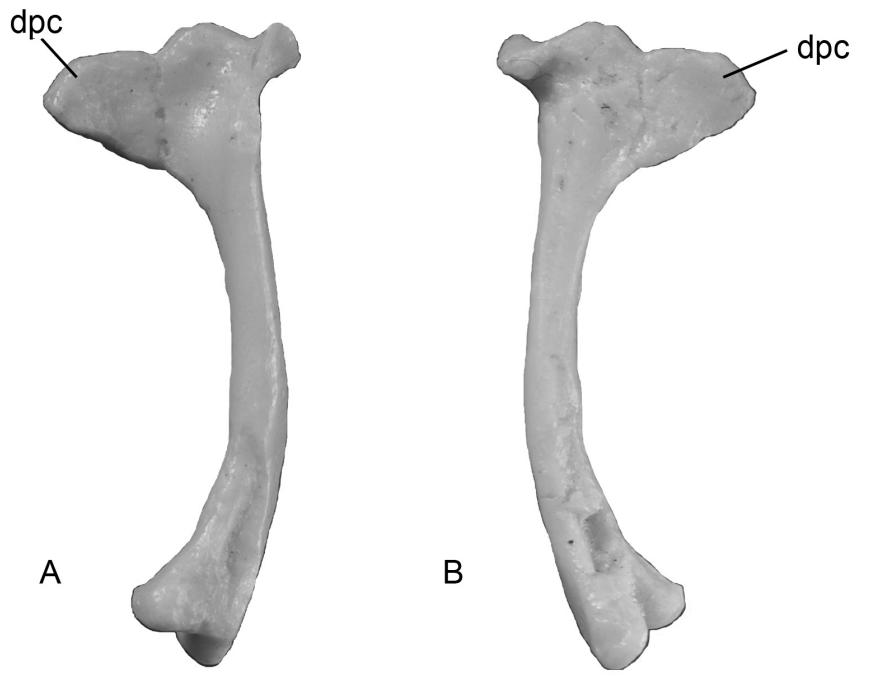

Fig. 3 - MB.R. 2833 in: A. medial view, B. lateral view; dpc - deltopectoral crest (scale $2 \mathrm{~cm}$ ).

The humerus shaft is bowed, with its diameter remaining constant for most of its length. At the distal portion a deep, well developed intertrochlear sulcus separates the lateral from the medial trochlea, with the lateral condyle being more prominent and projected when compared to the roller-shaped medial condyle. The distal end of the humerus is sub-triangular and lacks pneumatic foramina. 
TABLE II

Measurements (in mm) and proportions of MB.R. 2833.

\begin{tabular}{l|c}
\hline \multicolumn{1}{c|}{ Measurements } & Values \\
\hline Humeral length & 25.50 \\
\hline Deltopectoral crest lenght & 5.95 \\
\hline Length of attachment of deltopelctoral crest & 4.80 \\
\hline Deltopectoral crest/humeral length & 0.23 \\
\hline Proximal width & 10.44 \\
\hline Proximal width/humeral length & 0.41 \\
\hline Distal width/humeral length & 0.22 \\
\hline Minimum shaft diameter & 2.04 \\
\hline Minimum shaft diameter/humeral length & 0.08 \\
\hline
\end{tabular}

\section{COMPARISON AND DISCUSSION}

Both humeri from the Tendaguru deposits described here show a developed deltopectoral crest, which allows their allocation within Pterosauria. The deltopectoral crest of MB.R. 2828 differs from the most basal nonpterodactyloid pterosaurs by being longer and having the proximal margin curved and not straight such as reported in Sordes and Jeholopterus (Sharov 1971, Wang et al. 2002, Kellner 2003, Wang et al. 2009). It further lacks the hatched-shaped condition reported in the Rhamphorhynchidae and the sub-rectangular condition of the Campylognathoididae (Wellnhofer 1975, Wild 1978, Kellner 2003, Padian 2008). The most similar humerus of a non-pterodactyloid pterosaur is the one of Dorygnathus (Padian 2008). However, since MB.R. 2828 shows a well developed pneumatic foramen on the dorsal surface absent in all basal taxa, this specimen is referred to the Pterodactyloidea.

Pterodactyloid pterosaurs are divided into the Archaeopterodactyloidea and the Dsungaripteroidea. Up to date, no archaeopterodactyloid shows a pneumatic foramen on the humerus (Kellner 2004), leading us to classify MB.R. 2828 in the Dsungaripteroidea. Within that derived clade of pterosaurs, MB.R. 2828 does not show any particular affinity. This humerus lacks the warped and the hatched-shaped deltopectoral crest of the Pteranodontoidea and Nyctosauridae, respectively (Bennett 2001, Wang et al. 2005). It further differs from Tapejaridae and Azhdarchidae by the particular inclination of the deltopectoral crest that shows a distinct concave proximal margin in lateral view. This set of mor- phological features suggests that this specimen belongs to a new dsungaripteroid taxon, whose close affinities cannot be determined at this point.

The classification of the second specimen (MB.R. 2833 ) is less complicated. It differs from primitive pterosaurs by the shape of the deltopectoral crest and also differs from the Dsungaripteroidea by the lack of pneumatic foramen. MB.R. 2833 is similar to the humerus of several archaeopterodactyloids (e.g., Pterodactylus) and therefore is referred to this clade. Within the Archaeopterodactyloidea, all taxa show similar humeri with a long, proximally placed and curving ventrally deltopectoral crest, and the absence of pneumatic foramina. A sub-triangular distal end of the humerus is also observed in the Pteranodontoidea (Kellner 2003, Wang et al. 2009). However, no pteranodontoid pterosaur shows a well developed intertrochlear sulcus that is present in this Tendaguru specimen. Therefore, MB.R. 2833 is regarded as representing an undetermined species of Archaeopterodactyloidea. Based on the size and comparisons with other archaeopterodactyloid pterosaurs, this specimen represents a small individual, with an estimated wing-span around $35 \mathrm{~cm}$, making it the smallest pterosaur recorded from Africa so far.

\section{CONCLUSION}

As has been pointed out several times in the literature, the record of pterosaurs in terrestrial deposits is generally represented by incomplete specimens (e.g. Calvo et al. 2007). This is also the condition of pterosaurs record of Africa, for all in Tendaguru. 
As we have already discussed, there is no possibility to compare the humeri studied here (MB.R. 2828 and MB.R. 2833) with previously described pterosaur material from Tendaguru. Tendaguripterus recki was regarded as a Germanodactylidae (Unwin and Heinrich 1999) but is now considered as belonging to a distinct group of pterosaurs (Tendaguripteridae) whose relationships cannot be established at present (Kellner et al. 2007). Nonetheless, the presence of a Pterodactylus-like flying reptile as suggested by Reck (1931) or a similar archaeopterodactyloid species is corroborated by MB.R. 2833. The second specimen (MB.R. 2828), albeit representing a dsungaripteroid taxon, is sufficiently different from Dsungaripterus and other similar taxa.

Humerus has been used to diagnose new taxa (Price 1953, Buisonjé 1980, Wang et al. 2008) particularly concerning distinct shapes of the deltopectoral crest. In this respect, MB.R. 2828 indicates the presence of a new dsungaripteroid species in Africa whose close affinities cannot be established at this point. This new taxon lacks the diagnostic features of the Tapejaridae, Azhdarchidae, Pteranodontoidea and Nyctosauridae, suggesting that it might represent a new group of pterosaurs in the Jurassic of Africa. However, since the material is incomplete, we refrain from naming a new taxon, hoping that more complete material comes to light and allows a better characterization. Nonetheless, the fact that the humeri described here differ from each other indicates the presence of a diversified pterosaur fauna in Tendaguru during the Late Jurassic.

\section{ACKNOWLEDGMENTS}

We thank W. Heinrich for the access to the Tendaguru material, H. Silva for casting the original material, J. Sayão (Universidade Federal de Pernambuco, Vitória de Santo Antão) and D. Campos (Museu de Ciências da Terra - DNPM/ Rio de Janeiro) for comments on earlier version of the manuscript. This project was partially funded by the Conselho Nacional de Desenvolvimento Científico e Tecnológico (CNPq) (fellowship to FRC) with additional support by the Fundação Carlos Chagas Filho de Amparo à Pesquisa do Estado do Rio de Janeiro (FAPERJ, no. E-26/152.885/2006 to AWAK) and Conselho Nacional de Desenvolvimento Científico e Tecnológico (CNPq, no. 304965/2006-5 to AWAK).

\section{RESUMO}

Fragmentos de pterossauros africanos do Jurássico são excepcionalmente raros e conhecidos apenas dos depósitos de Tendaguru, Jurássico Superior, Tanzânia. Este estudo descreve dois úmeros direitos de pterossauros de Tendaguru depositados na Universidade Humboldt de Berlim: espécimes MB.R. 2828 (réplica MN 6661-V) e MB.R. 2833 (réplica MN 6666-V). MB.R. 2828 consiste em uma porção proximal com preservação tridimensional. Características morfológicas combinadas da crista deltopeitoral não observadas em outros pterossauros sugerem que este espécime pertença a um novo táxon dsungaripteróide. MB.R. 2833 é quase completo e, por causa da sua crista deltopeitoral extensa e arredondada, posicionada proximalmente, pode ser associado a Archaeopterodactyloidea. De qualquer forma, este é o menor pterossauro da África e um dos menores já registrados. Estes espécimes corroboram a importância dos depósitos de Tendaguru para registros de pterossauros jurássicos. Este potencial, no entanto, deve ser mais amplamente explorado com um maior número de trabalhos de campo.

Palavras-chave: Tendaguru, Tanzânia, África, Jurássico Superior, Pterosauria.

\section{REFERENCES}

BEnNETT SC. 1993. The ontogeny of Pteranodon and other pterosaurs. Paleobiology 19: 92-106.

BENNETT SC. 2001. The osteology and functional morphology of the Late Cretaceous pterosaur Pteranodon. Palaeontographica Abt A 26: 1-112.

BenNetT SC. 2003. Morphological evolution of the pectoral girdle of pterosaurs: myology and function. In: Buffetaut E And Mazin J-M (Eds), Evolution and Palaeobiology of Pterosaurs. London: Geol Soc Spec Pub, Geological Society, p. 191-215.

BUISONJÉ PH. 1980. Santanadactylus brasiliensis nov.gen., nov.sp., a long-necked, large pterosaur from the Aptian of Brasil. Proceedings of the Koninklijke Nederlande Akademie van Wetenschappen, B 83: 145-172.

Calvo JO, Porfiri JD, GonzÁlez-Riga B ANd KellNER AWA. 2007. A new Cretaceous terrestrial ecosystem from Gondwana with the description of a new sauropod dinosaur. An Acad Bras Cienc 79: 529-541.

Dalla Vecchia FM, ARduini P ANd Kellner AWA. 2001. The first pterosaur from the Cenomanian (Late Cretaceous) Lagerstätten of Lebanon. Cretaceous Res 22: 219-225. 
GALTON PM. 1980. Avian-like tibiotarsi of pterodactyloids (Reptilia: Pterosauria) from the Upper Jurassic of East Africa. Paläontologische Zeitschrift 54: 331-342.

HEINRICH WD. 1999. The taphonomy of dinosaurs from the Upper Jurassic of Tendaguru, Tanzania (East Africa), based on field sketches of the German Tendaguru expedition (1900-1913). Mitteilungen aus dem Museum für Naturkunde Berlin. Geowissenschaftliche Reihe 2: 2561.

JANENSCH W. 1914. Übersicht über die Wirbeltierfauna der Tendaguru-Schichten, nebst einer kurken Charakterisierung der neu aufgestellten Arten von Sauropoden. Archiv für Biontologie 3: 81-110.

Kellner AWA. 2003. Pterosaur phylogeny and comments on the evolutionary history of the group. In: BUfFETAUT E AND MAZIN J-M (Eds), Evolution and Palaeobiology of Pterosaurs. London: Geol Soc Spec Pub, Geological Society, p. 105-137.

Kellner AWA. 2004. New information on the Tapejaridae (Pterosauria, Pterodactyloidea) and discussion of the relationships of this clade. Ameghiniana 41: 521-534.

Kellner AWA AND Mader BJ. 1997. Archosaur teeth from the Cretaceous of Morocco. J Paleontol 71: 525527.

Kellner AWA And Tomida Y. 2000. Description of a new species of Anhangueridae (Pterodactyloidea) with comments on the pterosaur fauna from the Santana Formation (Aptian-Albian), Northeastern Brazil. National Science Museum Monographs 17: 1-135.

Kellner AWA, Martins A And Ford TL. 2007. A survey of pterosaurs from Africa with the description of a new specimen from Morocco. In: CARVALHO IS, CASSAB RCT, SchWanke C, Carvalho MA, FERnanDes ACS, Rodrigues MAC, Carvalho MSS, Arai M AND Oliveira MEQ (Eds), Paleontologia: Cenários de Vida. Rio de Janeiro: Interciência, p. 265-275.

Mader BJ ANd Kellner AWA. 1999. A new anhanguerid pterosaur from the Cretaceous of Morocco. Bol Mus Nac (nova série), Geol 45: 1-11.

Maier G. 1997. Tendaguru. In: Currie PJ ANd PAdian K (Eds), Encyclopedia of Dinosaurs. New York: Academic Press, p. 725-726.

PADIAN K. 2008. The Early Jurassic pterosaur Dorygnathus banthensis (Theodori, 1830). Spec Pap Palaeontol 80: $1-64$.

Pereda-Superbiola $\mathrm{X}$, Bardet N, Jouve S, IAroChÈne M, Bouya B And Amaghzaz M. 2003. A new azhdarchid pterosaur from the Late Cretaceous phosphates of Morocco. In: Buffetaut E AND MAZIN JM (Eds), Evolution and Palaeobiology of Pterosaurs. London: Geol Soc Spec Pub, Geological Society, p. 79-90.

PRICE LI. 1953. A presença de pterosauria no Cretáceo Superior do estado da Paraíba. Notas Preliminares e Estudos do DGM/DNPM 71: 1-10.

RECK H. 1931. Die deutschostafrikanischen Flugsaurier. Centralblatt für Mineralogie, Geologie und Paläontologie Abt B 7: 321-336.

SAYÃo JM AND Kellner AWA. 2001. New data on the pterosaur fauna from Tendaguru (Tanzania), Upper Jurassic, Africa. J Vertebr Paleontol 21 (Suppl): 97A.

Sharov AG. 1971. (New flying reptiles from the Mesozoic of Kazakhstan and Kirgizia). Trudy Academia Nauk SSSR, Palaeontoloitscheki Institut 130: 104-113. (In Russian.)

UNWIN DM AND HEINRICH WD. 1999. On a pterosaur jaw from the Upper Jurassic of Tendaguru (Tanzania). Mitteilungen Museum für Naturkunde Berlin 2: 121-134.

WANG X, Zhou Z, Zhang F AND XU X. 2002. A nearly completely articulated rhamphorhynchoid pterosaur with exceptionally well-preserved wing membranes and "hairs" from Inner Mongolia, northeast China. Chinese Sci Bull 47: 226-230.

Wang X, Kellner AWA, Zhou Z and Campos DA. 2005. Pterosaur diversity and faunal turnover in Cretaceous terrestrial ecosystems in China. Nature 437: 875879.

Wang X, Kellner AWA, Zhou Z and Campos DA. 2008. Discovery of a rare arboreal forest-dwelling flying reptile (Pterosauria, Pterodactyloidea) from China. Proc Nat Acad Sci 105(6): 1983-1987.

Wang X, Kellner AWA, Jiang S and Meng X. 2009. An unusual long-tailed pterosaur with elongated neck from western Liaoning of China. An Acad Bras Cienc 81: 793-812.

Wellnhofer P. 1975. Die Rhamphorhynchoidea (Pterosauria) der Oberjura Plattenkalke Süddeutschlands I-II. Palaeontographica A 148: 1-33.

Wellnhofer P and Buffetaut E. 1999. Pterosaur remains from the Cretaceous of Morocco. Paläontologische Zeitschrift 73: 133-142.

WILD R. 1978. Die Flugsaurier (Reptilia, Pterosauria) aus der Oberen Trias von Cene bei Bergamo, Italien. Bollettino della Società Paleontologica Italiana 17: 176-256. 